\title{
Slashing Phragmites (Phragmites australis) prior to planting does not promote native vegetation establishment
}

Joe Greet ${ }^{1}$ and Elise King ${ }^{1}\left({ }^{1}\right.$ School of Ecosystem and Forest Sciences, The University of Melbourne, Burnley, VIC, 3121, Australia). Email: greetj@unimelb.edu.au

\section{Acknowledgements}

We would like to thank: The Friends of the Helmeted Honeyeater nursery for supplying the plants; IndigWeDo for planting out the plots; and Miles Stewart-Howie, the Yellingbo Ranger, for making everything happen. We would also like to thank Sarah Fischer for field assistance and Sarah Moser for data management. This research was funded through Parks Victoria's Research Partners Panel (RPP1415 P07) and supported by the Australian Research Council Linkage program (LP150100682), with Melbourne Water, Parks Victoria, Zoos Victoria, and Greening Australia.

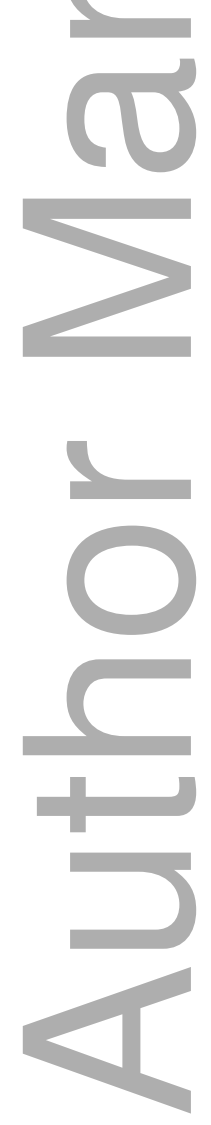

This is the author manuscript accepted for publication and has undergone full peer review but has not been through the copyediting, typesetting, pagination and proofreading process, which may lead to differences between this version and the Version of Record. Please cite this article as doi: $10.1111 /$ emr.12354

This article is protected by copyright. All rights reserved 
3

4

Article type : Short Report

6

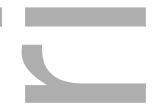

8 Slashing Phragmites (Phragmites australis) prior to planting does not

9 promote native vegetation establishment

\section{Summary}

Phragmites or Common Reed (Phragmites australis) is a tall rhizomatous cosmopolitan grass. While native to Australia, it can be invasive in wetlands, forming dense monocultures and reducing their ecological integrity. We assessed the potential for the cutting of Phragmites reeds prior to planting to promote the establishment of indigenous shrubs that might ultimately outcompete Phragmites.

We established ten $5 \mathrm{~m} \times 5 \mathrm{~m}$ quadrats in an area dominated by Phragmites, brush-cut the reeds to ground level in five of them and left five uncut as controls. Within each quadrat, we planted 20 plants ( $\sim 0 \mathrm{~cm}$ tall) of each of five indigenous shrub species, unguarded $\left(4\right.$ plants $\left./ \mathrm{m}^{2}\right)$. We surveyed the plants one month after planting and annually for the following four years for survival, height and browsing damage.

Browsing damage to plants was common ( $>50 \%$ ) and unaffected by cutting. After four years, overall plant survival rates were $\sim 25 \%$ and mean plant heights for the five shrub species ranged between 120-174 cm. Cutting of Phragmites had no positive effect on plant survival or height. In fact, two Melaleuca species grew taller in the uncut quadrats.

Cutting of Phragmites reed beds prior to planting is unlikely to promote the establishment of woody plantings. However, planting within established Phragmites with or without prior brush-cutting is

This article is protected by copyright. All rights reserved 
worthy of further trialling as a potential tool for reinstating native diversity at Phragmites-dominated sites.

\section{Keywords}

Woody plant establishment; wetland forest restoration; Phragmites australis; reed slashing; competition; plant invasions.

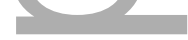

-

\section{Introduction}

Land-use changes and other anthropogenic impacts can favour invasive plants which can in turn alter ecosystems irrevocably. Phragmites or Common Reed (Phragmites australis) is a tall rhizomatous wetland grass species with a cosmopolitan distribution including Australia. It grows to 2-3 $\mathrm{m}$ tall and is tolerant of a broad range of water regimes in both freshwater and brackish ecosystems. It can reproduce both sexually and asexually, and often forms large dense clonal stands or reed beds (Roberts and Marston 2011). While Phragmites reed beds can provide important habitat for fauna, the species can be invasive in wetlands, forming monocultures, supressing native vegetation and reducing their ecological integrity (Silliman and Bertness 2004). Its extensive underground rhizomes and broad ecological niche make Phragmites particularly difficult to control, with control measures such as herbicides, brush-cutting/mowing, grazing, fire and flooding all being generally unsuccessful unless applied repeatedly or in concert (Hazelton et al. 2014; Marks et al. 1994).

In intact wetland forests in south-eastern Australia, Phragmites is often present, but in low abundances; presumably maintained through shading and competition for other resources. However, when forests are cleared, Phragmites can proliferate to form a dense monoculture precluding the regeneration of woody vegetation (Pearce 2000). There is some evidence to suggest that if woody wetland plants were able to re-establish and overtop the Phragmites, that Phragmites abundance may be suppressed (Ekstam 1995; Havens et al. 2003). Thus, accelerated forest succession may provide a management strategy whereby Phragmites removal could be coupled with planting trees and shrubs to shade out Phragmites (Hazelton et al. 2014).

In this study, we assessed the potential for the cutting of Phragmites reed beds prior to planting to promote the establishment and growth of planted shrubs with the aim of helping restore wetland forests. We expected that by removing the above-ground Phragmites biomass we would help accelerate the establishment of the plantings. Specifically, we predicted that seedlings planted in 
quadrats where Phragmites was cut would have higher survival rates and greater height growth compared to quadrats where brush-cutting was not undertaken.

\section{Methods}

\section{Study site}

Our field-based trial was conducted within the Yellingbo Nature Conservation Reserve $\sim 50 \mathrm{~km}$ east of Melbourne, Australia. The reserve supports wetland forests along several creeks that provide habitat for the critically endangered Leadbeater's Possum (Gymnobelideus leadbeateri) and Helmeted Honeyeater (Lichenostomus melanops cassidix) (Harley and Lill 2007; Pearce and Minchin 2001). These forests include Mountain Swamp Gum (Eucalyptus camphora)-dominated swamp forests on near permanently waterlogged sites, and shrub thickets of Leptospermum and Melaleuca species along swamp margins and ephemeral channels (Pearce and Minchin 2001). Phragmites is typically present but in low abundances in relatively undisturbed swampy areas, but is often dominant within disturbed (e.g. previously cleared) areas where it putatively precludes woody plant recruitment (Greet et al. 2016; Pearce 2000). In these habitats, only large older trees are present, or they are treeless and lack a midstorey. Our trial was established adjacent to the Cockatoo Creek on swamp margins in an area with large Mountain Swamp Gums and an understorey almost entirely dominated by Phragmites but with some native sedges and forbs also present in low abundances.

\section{Study design}

Ten $5 \mathrm{~m} \times 5 \mathrm{~m}$ quadrats were established in the summer of 2014. Within five of the quadrats, all the Phragmites reeds were cut at ground level (using a brush-cutter) and the thatch raked to the side. Reeds were cut in late summer as Phragmites growth is strongly seasonal: energy stored in its rhizomes feeds shoot growth in spring-summer with energy from its culms then recharged back to its rhizomes in autumn following seed set (Hocking 1989). Thus, timing of cutting for control is important and should be performed after flowering but prior to seed set. Reeds within the other five quadrats were not cut and functioned as controls. Quadrats were randomly allocated to either treatment group.

Within each quadrat, 100 shrubs were planted at a rate of 4 plants $/ \mathrm{m}^{2}$ (Appendix 1). This included 20 plants of each of 5 locally common habitat-forming shrub species: Yarra Burgan (Kunzea leptospermoides), Woolly tea-tree (Leptospermum lanigerum), Manuka (L. scoparium), Swamp Paperbark (Melaleuca ericifolia), and Scented Paperbark (M. squarrosa). These plants were not guarded despite high levels of browsing pressure within the area as it was anticipated that the 
surrounding Phragmites reed beds would provide some level of protection from browsers. The native browsers, Swamp Wallaby (Wallabia bicolor) and Common Wombat (Vombatus ursinus), and the non-native Sambar Deer (Rusa unicolor), Fallow Deer (Dama dama) and European Rabbit (Oryctolagus cuniculus) are all common at the site.

\section{Plant surveys}

The plantings were surveyed one month after being planted (March 2014) and in winter in each year for the next four years (2015-2018). For each survey, up to 10 seedlings of each species within each quadrat were haphazardly selected and their height recorded. In years 2015-2018, browsing damage to each surveyed seedling was scored using an ordinal scale (0 - absent, 1 - present, 2 common, 3 -prevalent). In 2016-2018, the total number of plants of each species within each quadrat were recorded to determine survival rates. While there was variable cover of Phragmites (mean $\pm \mathrm{SE}$ : cut, $66 \% \pm 14 \%$; uncut, $49 \% \pm 11 \%$ ), maximum flooding depth in any year (cut, $8 \mathrm{~cm} \pm$ $3 \mathrm{~cm}$; uncut, $15 \mathrm{~cm} \pm 6 \mathrm{~cm}$ ) and tree canopy cover (cut, $22 \% \pm 6 \%$; uncut, $24 \% \pm 4 \%$ ), these variables did not differ significantly between quadrats allocated to the two treatments (analyses not presented).

\section{Data analyses}

Survival rates for each species for the 2016-2018 surveys were calculated as the proportion of total live plants that were located out of the 20 plants that were initially planted within each quadrat. We modelled survival using beta regression as the response variable ranged between 0 and 1 (Ferrari and Cribari-Neto 2004). We used normal linear regression to model plant heights for the 2014-2018 surveys. Models for both survival and plants heights included Treatment (2 levels: cut, uncut), Year (survival model, 3 levels: 2016, 2017, 2018; heights model, five levels: 2014, 2015, 2016, 2017, 2018), and Species (5 levels) as fixed factors, with all possible interactions modelled (i.e. full model), with quadrat as a random factor. A similar model was fitted for browsing damage using ordinal regression (browsing was scored using an ordinal scale) but with four levels for Year $(2015,2016$, 2017, 2018). In the results, we present the results of Wald tests for the fixed effects and predicted means and standard errors (SEs) from the models. All analyses were done in R.

\section{Results}

Phragmites stands completely regrew after 1 year (Appendix 1 ), however culms were noticeably shorter ( $\sim 1.5 \mathrm{~m}$ cf. 2-2.5 m) and skinnier in quadrats where culms had been cut the previous year (a typical response to cutting for this species; Greet and Rees 2015). Of the 1000 seedlings planted in 
2014, 375, 281 and 243 were relocated in years 2016, 2017 and 2018, respectively. Very few dead plants were located $(<2 \%$ in any given year, typically desiccated Woolly Tea-tree plants, which are particularly flood-dependent) and most plants surveyed appeared in good condition. It is suspected that the relatively low numbers of plants able to be relocated was largely due to plant loses due to browsing; browsing damage to located plants was common ( $>50 \%$ of plants).

There were no significant differences in survival rates between the cut and uncut treatments overall (pooling across species and years; $p=0.585$ ), or at the species level; however, Swamp Paperbarks tended to survive better in the cut treatment compared to the uncut treatment $(p=0.088)$. Overall, plant survival rates were $25 \%$ after four years (2018), while Scented Paperbarks had the highest survival rate (36\%) and Woolly Tea-tree the lowest (23\%) (Appendix 2).

Similarly, there was no positive effect of cutting Phragmites on plant heights overall $(p=0.228)$. In fact, plant heights for both Melaleuca species were taller in the uncut than in the cut quadrats (2018 means: M. ericifolia, $192 \mathrm{~cm}$ v $156 \mathrm{~cm}$; M. squarrosa, $224 \mathrm{~cm}$ v $119 \mathrm{~cm}$ ) (Figure 1). Swamp Paperbarks and Scented Paperbarks were tallest $(174 \mathrm{~cm}$ and $171 \mathrm{~cm}$, respectively) and Woolly Teatree shortest $(120 \mathrm{~cm})$ (Figure 3). Two Swamp Paperbarks and 10 Scented Paperbarks were observed flowering in 2018.

Browsing damage to plants was prevalent (76\%, 73\%, 59\% and 57\% of plants surveyed in 2015, 2016, 2017 and 2018 respectively). Typically, browsed but extant plants had been 'tip pruned', but had produced lateral shoots and appeared healthy. There were no differences in browsing damage scores between the cut and uncut treatments overall $(p=0.152)$, while Yarra Burgan plants were least browsed compared to the other four species $(p<0.001)$.

\section{Discussion}

Contrary to our expectations, the cutting of Phragmites reeds prior to planting did not promote the establishment or growth of planted shrubs. In fact, the two Melaleuca species grew taller when planted directly into uncut reed beds. Regardless, considerable numbers of shrubs established (>1 plants $/ \mathrm{m}^{2}$ ) in both cut and uncut areas at four years post-planting. These plants, as they continue to increase in cover, will potentially reduce the dominance of Phragmites (Ekstam 1995; Havens et al. 2003) and restore critical midstorey habitat where it has been previously cleared.

The cutting of Phragmites was not intended, or expected to, control Phragmites. As expected, Phragmites reed beds recovered completely after one year via resprouts from its extensive below- 
ground biomass (principally rhizomes, Phragmites is virtually absent from the the local soil seed bank; Greet 2016). It is likely that this occurred before the planted shrubs could develop extensive root systems to fuel growth. Plants were planted towards the end of the growing season, when cutting of reeds is most effective. Phragmites shoots readily resprouted at the beginning of the following growing season, and the transient reduction in competition for light via cutting proved ineffective in promoting shrub growth. Moreover, the greater competition for light in uncut reed beds may have promoted those shrubs planted in them to grow taller than shrubs planted in cut red beds in which the resprouting culms were shorter.

Despite the high levels of browsing pressure and associated plant losses, after four years most established plants were in good condition and had almost grown level with the Phragmites. Indeed, many plants were already taller than the extant reeds, i.e. there were 52 plants $>2 \mathrm{~m}$ tall. Furthermore, some of the taller plants had already reached sexual maturity, i.e. they were flowering and possessed woody capsules. This suggests that while Phragmites may inhibit woody plant seedling recruitment (e.g. via allelopathic effects; Uddin and Robinson 2015), where water and nutrients are not limiting, planted trees/shrubs may be able to persist and eventually grow taller and out-compete Phragmites. This has previously been proposed as a potential method of Phragmites control (Hazelton et al. 2014) and has been demonstrated for other wetland systems with similarly dense understorey vegetation (McLeod et al. 2000). While the sample size was small, our results suggest that planting trees/shrubs within established reed beds is worthy of further trialling as an appropriate approach to revegetating Phragmites-dominated sites and restoring wetland forests.

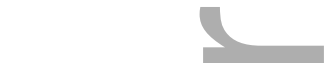

\section{References}

Ekstam B (1995) Ramet size equalisation in a clonal plant, Phragmites australis. Oecologia 104, 440446.

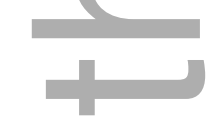

Ferrari S and Cribari-Neto F (2004) Beta regression for modelling rates and proportions. Journal of Applied Statistics 31, 799-815.

Greet J (2016) The potential of soil seed banks of a eucalypt wetland forest to aid restoration. Wetlands Ecology and Management 24, 1-13. 
184

185

186

187

188

189

190

191

192

193

194

195

196

197

198

199

200

201

202

203

204

205

206

207

208

209

210

211

212

213

Greet J, King E and Stewart-Howie M (2016) Plastic weed matting is better than jute or woodchips for controlling the invasive wetland grass species Phalaris arundinacea, but not Phragmites australis. Plant Protection Quarterly 31, 19-22.

Greet J and Rees P (2015) Slashing may have potential for controlling Phragmites australis in longinundated parts of a Ramsar-listed wetland. Ecological Management \& Restoration 16, 233-236.

Harley DKP and Lill A (2007) Reproduction in a population of the endangered Leadbeater's Possum inhabiting lowland swamp forest. Journal of Zoology 272, 451-457.

Havens KJ, Berquist H and Priest WI (2003) Common reed grass, Phragmites australis, expansion into constructed wetlands: are we mortgaging our wetland future? Estuaries 26, 417-422.

Hazelton EL, Mozdzer TJ, Burdick DM, Kettenring KM and Whigham DF (2014) Phragmites australis management in the United States: 40 years of methods and outcomes. AoB plants 6 , https://doi.org/10.1093/aobpla/plu001.

Hocking P (1989) Seasonal dynamics of production, and nutrient accumulation and cycling by Phragmites australis (Cav.) Trin. ex Stuedel in a nutrient-enriched swamp in inland Australia. I. Whole plants. Marine and Freshwater Research 40, 421-444.

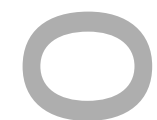

Marks M, Lapin B and Randall J (1994) Phragmites australis (P. communis): threats, management and monitoring. Natural Areas Journal 14, 285-294.

McLeod KW, Reed MR and Wike LD (2000) Elevation, competition control, and species affect bottomland forest restoration. Wetlands 20, 162-168.

Pearce J (2000) Mountain swamp gum Eucalyptus camphora at Yellingbo State Nature Reserve: habitat use by the endangered Helmeted Honeyeater Lichenostomus melanops cassidix and implications for management. The Victorian Naturalist 117, 84-92.

This article is protected by copyright. All rights reserved 
Pearce J and Minchin PR (2001) Vegetation of the Yellingbo Nature Conservation Reserve and its

relationship to the distribution of the Helmeted Honeyeater, Bell Miner and White-eared

217

Honeyeater. Wildlife Research 28, 41-52.

218

Roberts J and Marston F (2011) 'Water regime for wetland and floodplain plants: a source book for the Murray-Darling Basin.' (National Water Commission: Canberra, Australia).

221

Silliman BR and Bertness MD (2004) Shoreline development drives invasion of Phragmites australis

Uddin N and Robinson R (2015) Allelopathy and Phragmites: Death in the wetland. In 'Managing

Typha and Phragmites workshop' (Eds J Roberts and H Kleinert), North Central CMA.
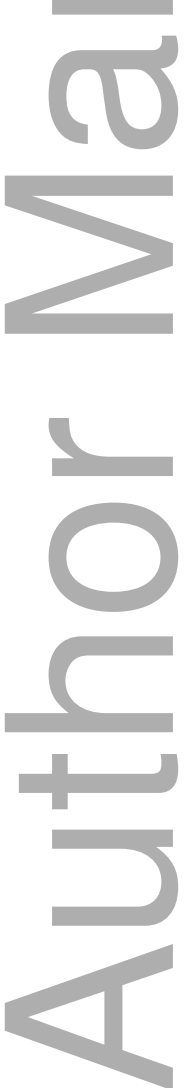

This article is protected by copyright. All rights reserved 

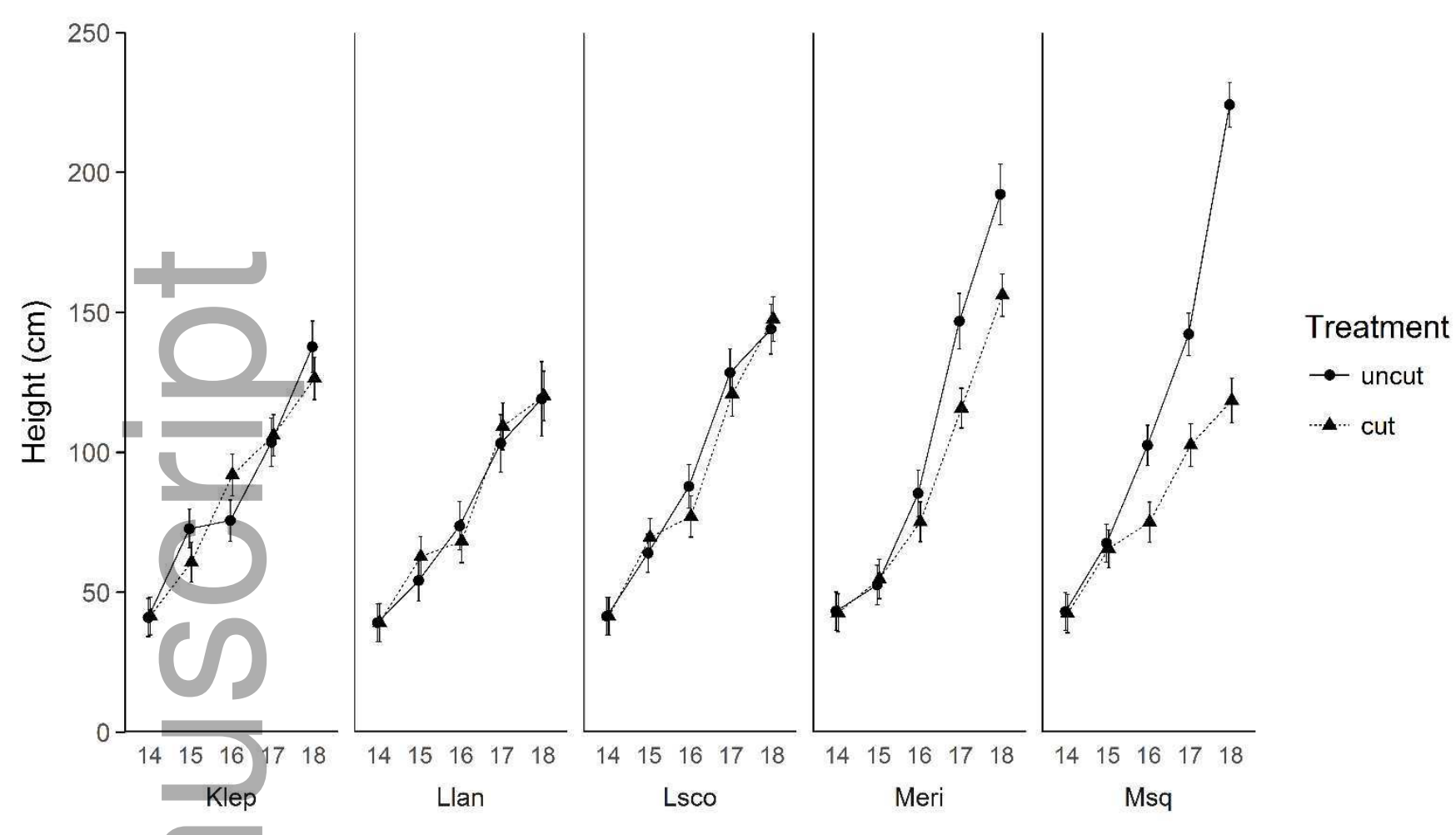

Figure 1. Mean $( \pm S E)$ plant height of five shrub species planted within cut and uncut Phragmites over time from planting in 2014 to present (2018). Species codes: Klep - Kunzea leptospermoides; Llan - Leptospermum lanigerum; Lsco Leptospermum scoparium; Meri - Melaleuca ericifolia; Msq - Melaleuca squarrosa.

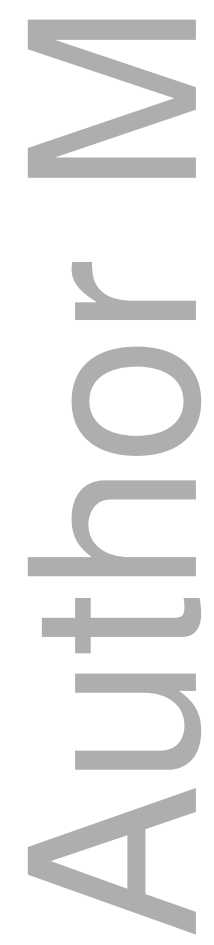

This article is protected by copyright. All rights reserved 


\section{University Library}

\section{- M M N E R VA A gateway to Melbourne's research publications}

Minerva Access is the Institutional Repository of The University of Melbourne

Author/s:

Greet, J;King, E

Title:

Slashing Phragmites (Phragmites australis) prior to planting does not promote native vegetation establishment

Date:

2019-05-01

Citation:

Greet, J. \& King, E. (2019). Slashing Phragmites (Phragmites australis) prior to planting does not promote native vegetation establishment. ECOLOGICAL MANAGEMENT \& RESTORATION, 20 (2), pp.162-165. https://doi.org/10.1111/emr.12354.

Persistent Link:

http://hdl.handle.net/11343/285277 